\title{
HUBUNGAN SELF-MANAGEMENT DENGAN KUALITAS HIDUP PASIEN PASCA STROKE DI RSUD ENCIK MARIYAM TAHUN 2020
}

\author{
Elsa Marviana, Sri Muharni, Utari Christya Wardhani \\ STIKes Awal Bros Batam, Indonesia \\ Email : vianaelsa32@gmail.com,muharnisri@gmail.com,dan \\ wardhaniutari@yahoo.co.id
}

\begin{tabular}{l}
\hline INFO ARTIKEL \\
\hline Tanggal diterima: 5 September \\
2020 \\
Tanggal revisi: 10 September \\
2020 \\
Tanggal yang diterima: 25 \\
September 2020 \\
Kata Kunci: \\
Self-Management; Pasca \\
Stroke; Kualitas Hidup.
\end{tabular}

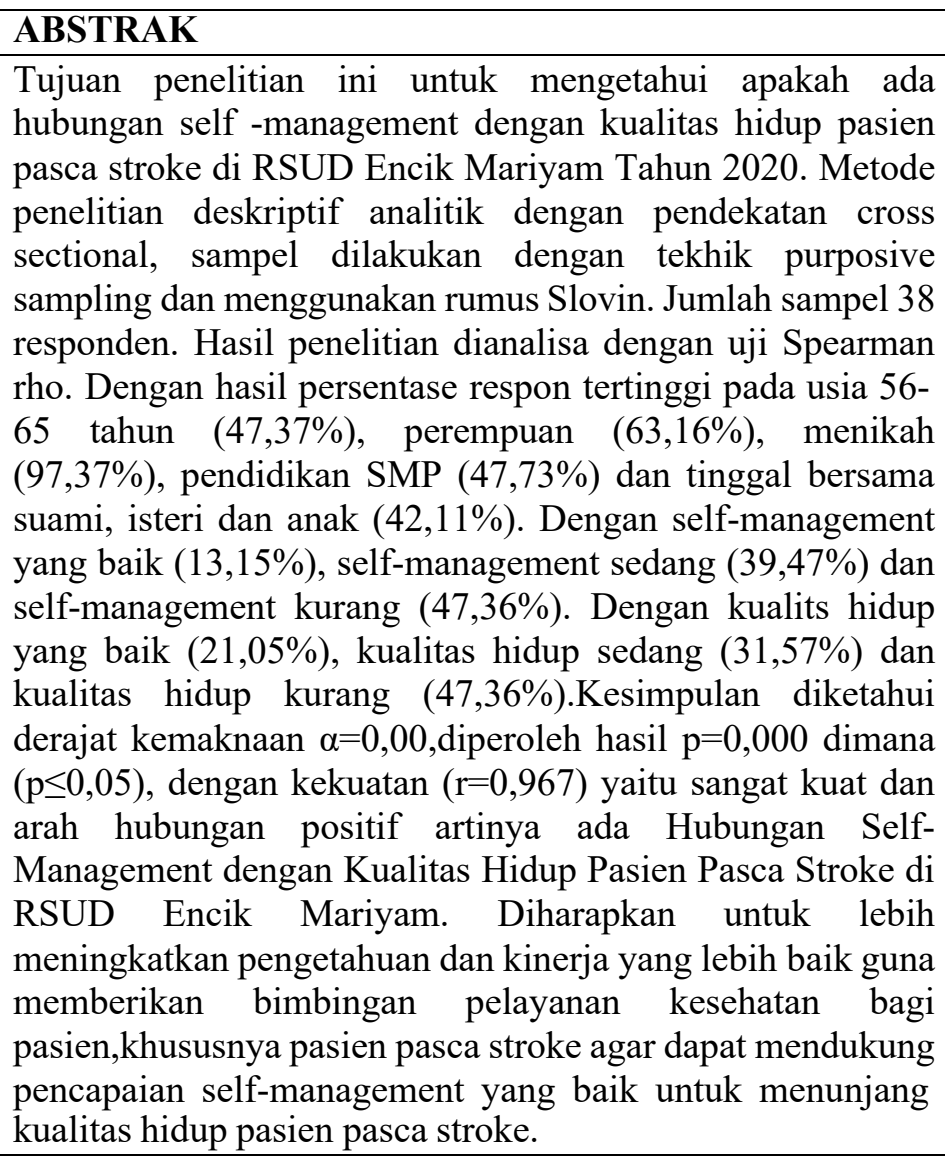

\section{Pendahuluan}

Stroke yaitu matinya jaringan otak (infark cerebral) yang di karenakan minusnya aliran darah dan $\mathrm{O} 2$ ke dalam otak. Stroke dapat berupa iskemik atau pun pendarahan (hemora-gik). "Pada stroke iskemik, aliran darah ke otak terputus, di temukan bekuan darah yang telah menghalangi suatu pembuluh darah" (Prasetyono 2012). Stroke adalah suatu kondisi karena adanya gangguan peredaran darah pada otak yang menyebabkan kematian jaringan otak serta seseorang mengalami kelumpuhan atau kematian (Ginting, 2019). Stroke adalah penyakit neurologi yang paling mengancam kehidupan dan merupakan penyebab kematian nomor 3 di Amerika Serikat setelah penyakit jantung dan kanker (Price \& Wilson, 2016). Pasien stroke pada dasarnya tetap mempunyai potensi buat sembuh sesudah mengalami penyakit stroke. Akan tetapi, pasien yang sanggup melangsungkan hidup setelah terkena stroke mempunyai kendala dalam meneruskan kehidupannya. Setengah dari pasien pasca stroke akan merasakan gejala sisa serangan stroke yang sangat beragam, yakni gangguan gerak atau pun motorik, gangguan penglihatan, gangguan bicara, perubahan emosi, serta 
gejala lain sesuai lokasi otak yang mengalami penyumbatan (Misbach et al., 2014). Menurut penelitian (Riyadina, 2013) mengatakan bahwa masyarakat yang menderita hipertensi berisiko 4 kali lebih besar untuk mengalami penyakit stroke (OR $=4,20$; CI $95 \%=2,20-8,03$. Setengah dari pasien pasca stroke juga akan mendapatkan gejala sisa penyakit stroke yang beragam, misalkan gangguan gerak atau motorik, gangguan penglihatan, gangguan bicara, perubahan emosi, serta gejala lain sesuai lokasi otak yang mengalami penyumbatan (Misbach et al., 2014). Gangguan ini dapat berakibat pada aspek fisik, psikologis dan sosial bagi pasiennya, juga akan berakibat pada kurangnya aktivitas dan kualitas hidup baik selamanya atau pun dalam waktu singkat.

World Health Organization Quality of Life (WHOQOL) mengartikan kualitas hidup sebagai suatu pandangan seseorang tentang cara hidupnya di kehidupan sosial dalam istilah kebudayaan, norma-norma yang ada yang berhubungan dengan tujuan hidup, asa, standart, dan kepedulian. Kualitas hidup adalah sebuah fenomena dalam jangkauan besar yang berlandaskan kondisi fisik seseorang, psikologis, tingkat kemandirian, dan hubungan seseorang dengan lingkungannya (Yuliati, Baroya, \& Ririanty, 2014). "Penderita yang terkena stroke mencapai 8,3 per 100 penduduk di Indonesia dengan penduduk sekitar 211 juta jiwa, berarti terdapat sekitar 1,7 juta penderita stroke di Indonesia" (Solehin \& Hamzah, 2016). "Setiap tahun bias saja ada 500.000 jiwa mengalami penyakit stroke, sekitar 2,5\% atau 125.000 jiwa akan meninggal dunia, selebihnya cacat ringan ataupun berat. Secara global, bisa di lihat kasus stroke sekitar 200 per 100.000 jiwa.Selama 1 tahun, rentang 100.000 jiwa, maka 200 jiwa mengalami serangan stroke" (Indonesia, 2012). Penderita stroke akan mengalami kehilangan fungsi motorik dan sensorik yang mengakibatkan hemiparesis, hemiplegia, serta ataksia. Akibat adanya gangguan motorik pada otak, maka otot akan diistirahatkan sehingga menyebabkan atrofi otot. Atrofi otot menyebabkan kekakuan otot, sehingga otot yang kaku tersebut dapat mengalami keterbatasan gerak pada pasien stroke (Ariani, 2012).

Menurut (Kemenkes, 2016) berdasarkan laporan kementerian kesehatan Republik Indonesia Tahun 2016 angka yang terkena stroke di Indonesia Tahun 2015 sesuai dengan diagnosis Tenaga Kesehatan yaitu ada 1.236.825 jiwa. Di Indonesia sendiri, stroke merupakan penyebab utama kematian dengan prevalensi berdasarkan Riset Kesehatan Dasar (Riskesdas) tahun 2007 adalah 8 kasus per 1000 jiwa (Sedyaningsih, 2011). Sedangkan penderita stroke dengan diagnosis Nakes sebanyak 19.044 jiwa. Sesuai Survailans Penyakit Tidak Menular Bidang P2PL Dinas Kesehatan Provinsi Kepulauan Riau tahun 2018, ada 423 penderita stroke lama dan terdapat 261 kasus penderita baru di Provinsi Kepulauan Riau. (Mustafa \& Ibrahim, 2020). Dari data jumlah kunjungan pasien di RSUD Encik Mariyam Lingga tahun 2018 diperoleh data sebanyak 74 orang penderita stroke yang dirawat diruang rawat inap dan sebanyak 43 orang pasien pasca stroke yang melakukan kunjungan kontrol ke instalasi rawat jalan. Stroke pada usia muda relatif jarang dibanding kelompok usia lanjut, tetapi memiliki penyebab dan metode diagnostik yang khusus, berpotensi menyebabkan hilangnya kemampuan di usia produktif, dan memberikan dampak psikososial yang berat (Birawa \& Amalia, 2015)."Adapun solusi penanganan terhadap pasien stroke adalah meningkatkan self-management pasien".

Penambahan usia tidak Selfmanagement diartikan sebagai skill individu untuk mengatur gejala, pengobatan, konsekuensi fisik, psikis, dan 
perubahan gaya hidup. Self-management ini diukur dengan menggunakan SSMQ, tiap point di dalamnya dapat digambarkan sebagai sebuah attitude, behaviour, dan skill. "Kuesioner ini mengukur empat domain dari penderita pasca stroke, yaitu kapasitas, kepercayaan diri dalam berinteraksi, strategi, dan bimbingan oleh professional kesehatan" (Fryer, Luker, McDonnell, \& Hillier, 2016).

Hasil dari studi pendahuluan di RSUD Encik Mariyam pada bulan Juli 2019 sampai dengan September 2019 telah terdata 24 pasien stroke yang dirawat dan 18 pasien pasca stroke yang tercatat dalam kunjungan poli rawat jalan dengan pengobatan dan kunjungan rumah selama tiga bulan terakhir.

\section{Metode Penelitian}

Desain penelitian ini berupa kuantitatif. Penelitian yang dilakukan adalah penelitian observasional dengan menggunakan desain non-experiment studi korelasi. "Jenis penelitian yag digunakan adalah deskriptif korelasional dan pendekatan adalah cross sectional dimana peneliti mencoba menggali bagaimana Hubungan Self-Management dengan Kualitas Hidup Pasien Pasca Stroke Di RSUD Encik Mariyam Tahun 2020" (Nursalam, 2014). Pemilihan sampel dilakukan dengan teknik purposive sampling dengan menggunakan rumus Slovin. Jumlah sampel yang digunakan sebanyak 38 responden. Hasil penelitian dianalisa dengan uji Spearman rho.

\section{Hasil Penelitian}

\section{Distribusi frekuensi berdasarkan karakteristik responden.}

\section{Tabel 1}

Distribusi Frekuensi Karakteristik

Usia,Jenis Kelamin, Status perkawinan, Pendidikan, dan Tempat Tinggal

\begin{tabular}{|c|c|c|c|}
\hline \multicolumn{4}{|c|}{ Responden } \\
\hline $\mathrm{No}$ & Karakteristik & $\mathrm{f}$ & $\%$ \\
\hline \multirow[t]{5}{*}{1} & Usia & & \\
\hline & a. 35-45 tahun & 2 & 5,26 \\
\hline & b. 46-55 tahun & 8 & 21,05 \\
\hline & c. 56-65 tahun & 18 & 47,37 \\
\hline & d. 66-75 tahun & 10 & 26,32 \\
\hline \multirow[t]{3}{*}{2} & Jenis kelamin & & \\
\hline & a. Laki laki & 14 & 36,84 \\
\hline & b. Perempuan & 24 & 63,16 \\
\hline \multirow[t]{3}{*}{3} & Status perkawinan & & \\
\hline & a. Menikah & 37 & 97,37 \\
\hline & $\begin{array}{ll}\text { b. Belum } \\
\text { menikah }\end{array}$ & 1 & 2,63 \\
\hline \multirow[t]{5}{*}{4} & Pendidikan & & \\
\hline & a. $\mathrm{SD}$ & 12 & 31,58 \\
\hline & b. SMP & 18 & 47,37 \\
\hline & c. SMU/ SMK & 6 & 15,79 \\
\hline & d. PT & 2 & 5,26 \\
\hline \multirow[t]{9}{*}{5} & Tempat tinggal & & \\
\hline & a. Tinggal & 0 & 0 \\
\hline & sendiri & 2 & 5,26 \\
\hline & . bersama & 8 & 21,05 \\
\hline & saudara & 12 & 31,58 \\
\hline & c. bersama anak & 16 & 42,11 \\
\hline & $\begin{array}{l}\text { d. } \begin{array}{l}\text { Bersama } \\
\text { suami/isteri }\end{array}\end{array}$ & & \\
\hline & e. Bersama & & \\
\hline & $\begin{array}{l}\text { Suami/istri } \\
\text { dan anak }\end{array}$ & & \\
\hline
\end{tabular}

2. Distribusi frekuensi SelfManagement Pasien Pasca Stroke.

Tabel 2

Distribusi Self- Management Pasien Pasca Stroke

\begin{tabular}{ccc} 
Self-Management & $\mathrm{F}$ & $\%$ \\
\hline Baik & 5 & 13,15 \\
Sedang & 15 & 39,47 \\
Kurang & 18 & 47,36 \\
\hline Total & $\mathbf{3 8}$ & $\mathbf{1 0 0}$
\end{tabular}

Dari tabel 2 didapat hasil bahwa responden dengan distribusi selfmanagement terbanyak yaitu responden dengan self-management kurang yaitu sebanyak 18 orang $(47,36 \%)$. 
3. Distribusi Frekuensi Kualitas Hidup Pasien Pasca Stroke.

Tabel 3

Distribusi Kualitas Hidup Pasien Pasca Stroke

\begin{tabular}{ccc}
\hline Kualitas hidup & $\mathrm{f}$ & $\%$ \\
\hline Baik & 8 & 21,05 \\
Sedang & 12 & 31,57 \\
Kurang & 18 & 47,36 \\
\hline Total & $\mathbf{3 8}$ & $\mathbf{1 0 0}$ \\
\hline
\end{tabular}

Dari Tabel 3 diatas, distribusi kualitas hidup pasien pasca stroke terbanyak yaitu kualitas hidup kurang sebanyak 18 orang $(47,36 \%)$.

4. Hubungan self-management dengan kualitas hidup pasien pasca stroke.

Hubungan self-management dengan kualitas hidup pasien pasca stroke di RSUD Encik Mariyam Tahun 2020 dianalisis dengan uji statistik korelasi Spearman rho dengan bantuan program SPSS 22.0. for windows dengan derajat kemaknaan $\alpha=0,05$.

Tabel 4

hasil uji korelasi Spearman

\begin{tabular}{lc}
\hline & Kualitas hidup \\
\hline & $\mathrm{r}$ \\
Self-management & 0,967 \\
\hline & $\mathrm{p}$ \\
& $\mathrm{n}, 000$ \\
Terdapat $\quad$ hubungan yang \\
signifikan antara self-management \\
dengan kualitas hidup dengan derajat \\
kemaknaan $\alpha=0,00$, diperoleh hasil \\
p=0,000 dimana ( $\leq 0,05$ ), dengan \\
kekuatan (r=0,967) yaitu sangat kuat \\
dan arah hubungan positif artinya \\
koefisien korelasi adalah signifikan,
\end{tabular}

sehingga H0 ditolak dan Ha diterima, yang berarti ada Hubungan SelfManagement dengan Kualitas Hidup Pasien Pasca Stroke di RSUD Encik Mariyam Lingga Tahun 2020.

\section{Pembahasan Penelitian}

\section{Analisa Univariat}

a. Distribusi Self-Management Pasien Stroke.

Dari penelitian didapat hasil bahwa responden dengan kriteria self-management pasien pascastroke yaitu responden dengan selfmanagement baik sebanyak 5 orang $(13,15 \%)$, self-management sedang sebanyak 15 orang $(39,47 \%)$ dan self-management kurang sebanyak 18 orang $(47,36 \%)$.

Distribusi responden berdasarkan self-management pasien pasca stroke merupakan hasil pencapaian jawaban responden terhadap kuesioner dari 28 pertanyaan pada lembar kuesioner Self-Management Questionnaire (SSMQ).

Peneliti memperoleh kesimpulan bahwa self-management pasien pasca stroke di RSUD Encik Mariyam tergolong kurang baik, hal ini dapat dilihat dari hasil penelitian, dimana berdasarkan hasil pengisian quesioner di dapatkan kategori tertinggi pada self-management kurang yaitu sebanyak 18 orang (47,36\%). Self-management pasien stroke akan baik apabila pasien dapat menerapkan domain kapasitas, strategi, kepercayaan diri, dan bimbingan tenaga kesehatan untuk bertahan dengan kondisi pasca strokenya. Untuk itu perlu adanya peran serta dari tenaga kesehatan dalam memberikan bimbingan terhadap pasien dan keluarga untuk 
dapat meningkatkan selfmanagement pasien pasca stroke. Selain itu peran serta keluarga juga sangat diharapkan untuk dapat mengsupport pasien dalam meningkatkan self-management.

b. Distribusi Kualitas Hidup Pasien Stroke.

Dari hasil penelitian didapatkan distribusi kualitas hidup pasien stroke yaitu kualitas hidup baik sebanyak 8 orang $(21,05 \%)$, kualitas hidup sedang sebanyak 12 orang (31,57\%) dan kualitas hidup kurang sebanyak 18 orang $(47,36 \%)$.

Peneliti berasumsi bahwa kualitas hidup pasien stroke di RSUD Encik Mariyam Lingga berdasarkan hasil penelitian didapatkan hasil bahwa sebagian besar pasien memiliki kualitas hidup kurang baik yang dibuktikan dengan hasil penelitian kualitas hidup pasien stroke terbanyak yaitu kualitas hidup kurang baik sebanyak 18 orang (47,36\%). namun ada beberapa pasien yang memiliki kualitas hidup baik yaitu sebanyak 8 orang $(21,05 \%)$ dengan domain terganggu yang paling tinggi adalah kurangnya dukungan keluarga.

2. Analisa hubungan selfmanagement dengan kualitas hidup pasien pasca stroke.

Terdapat "hubungan yang signifikan antara self-management dengan kualitas hidup dengan derajat kemaknaan $\alpha=0,00$, diperoleh hasil $\mathrm{p}=0,000$ dimana $(p \leq 0,05)$, dengan kekuatan $(r=0,967)$ yaitu sangat kuat dan arah hubungan positif artinya koefisien korelasi adalah signifikan, sehingga H0 ditolak dan Ha diterima, yang berarti ada Hubungan Self-Management dengan Kualitas Hidup Pasien Pasca Stroke di RSUD Encik Mariyam Lingga Tahun 2020".

\section{BIBILIOGRAFI}

Ariani, Dorothea Wahyu. (2012). LeaderMember Exchanges As A Mediator Of The Effect Of Job Satisfaction On Affective Organizational Commitment: An Empirical Test. International Journal of Management, 29(1), 46.

Birawa, Andi Basuki Prima, \& Amalia, Lisda. (2015). Stroke Pada Usia Muda. Cermin Dunia Kedokteran, 42(10), 736-739.

Fryer, Caroline E., Luker, Julie A., McDonnell, Michelle N., \& Hillier, Susan L. (2016). Self-Management Programs For Quality Of Life In People With Stroke. Stroke, 47(12), e266-e267.

Ginting, Ghea Karina Alemina. (2019). Tugas Perawat Dalam Menerapkan Keselamatan Pasien Stroke Dirumah Sakit.

Indonesia, Yayasan Stroke. (2012). Kejadian Stroke Berulang Berisiko Tinggi Timbulkan Kematian. 19 September 2016.

Kemenkes, R. I. (2016). Profl Kesehatan RI Tahun 2016. Jakarta, Kementrian Kesehatan RI.

Kusumaningrum, M., \& CI, S. (Prasetyono (2012). Kualitas kimia ransum sapi potong berbasis limbah pertanian dan hasil samping pertanian dan hasil pertanian yang difermentasi dengan Aspergillus niger. Anim. Agrculture, 1(2), 109-119.

Misbach, Charlotte, Chetboul, Valérie, Concordet, Didier, Médaille, Christine, Gruet, Philippe, Speranza, Cindy, 
Hoffmann, Anne-Cécile, Rocha, Adriana, Balouka, David, \& Petit, Amandine M. P. (2014). Basal Plasma Concentrations Of Routine Variables And Packed Cell Volume In Clinically Healthy Adult Small-Sized Dogs: Effect Of Breed, Body Weight, Age, And Gender, And Establishment Of Reference Intervals. Veterinary Clinical Pathology, 43(3), 371-380.

Mustafa, Darlaini, \& Ibrahim, Ibrahim. (2020). Hubungan Pengetahuan Dan Sikap Ibu Dengan Pemberian Asi Eklusif Di Wilayah Kerja Upt Puskesmas Meral Kabupaten Karimun Provinsi Kepulauan Riau Tahun 2018. Zona Kebidanan: Program Studi Kebidanan Universitas Batam, 9(2).

Nursalam, Mnurs. (2014). Manajemen Keperawatan. Jakarta: Salemba Medika.

Price, Sylvia A., \& Wilson, Lorraine M. (2006). Patofisiologi konsep klinis proses-proses penyakit. Jakarta: Egc, $4(2), 1127-1128$.

Riyadina, W. (2013). Rahajeng E. Determinan Penyakit Stroke. Kesmas, 7(7), 324-330.
Sedyaningsih, E. R. (2011). Stroke Penyebab Utama Kematian Di Indonesia. Sambutan Menkes Pada Peringatan Hari Stroke Sedunia.

Solehin, M. M., \& Hamzah, Nurhikmah. (2016). Analysis Of Risk Factors Of Stroke Incidence In RSUD Balangan And Puskesmas Balangan 2016. Caring, 2(2), 73-87.

\section{Copyright holder:}

Elsa Marviana, Sri Muharni, Utari Christya Wardhani (2020)

First publication right:

Jurnal Health Sains

This article is licensed under: 